\title{
Analiza trendów w kontekście hermeneutyki i myślenia prospekcyjnego
}

\author{
Andrzej Kucner \\ (Uniwersytet Warmińsko-Mazurski w Olsztynie, Instytut Filozofii)
}

\section{Wprowadzenie}

Swoje rozważania poświęcę analizie trendów jako swoistemu i zyskującemu na znaczeniu sposobowi analizowania zmian, którego wyróżnikiem jest dążenie do ich rozumienia oraz równoczesnego wartościowania, a kontekstem podejmowanych badań jest przyszłość. Każdy z tych celów łączy się z odmienną strategią analizy zmian. W pierwszym przypadku, gdy chodzi o rozumienie, analiza trendów polega na dążeniu do uchwycenia zmian istotnych, wpływających na myślenie i postępowanie ludzi, formy życia, kierunki rozwoju kultury, po to by sformułować ich możliwe spójną wykładnię. W drugim przypadku wartościowanie wynikające $\mathrm{z}$ analizowania trendów pozwala rozumieć znaczenie zachodzących procesów oraz tego, co może wynikać z nich w przyszłości. Próby wartościowania zmian pozwalają na ich hierarchizację oraz sensotwórczą interpretację. Wyróżnikiem trendów, zróżnicowanych zasięgiem, skalą i siłą oddziaływania, jest ich realny wpływ na wiedzę, działanie społeczeństwa, kulturę, gospodarkę i politykę.

W ostatnich kilkunastu latach analiza trendów jako podejście badawcze zyskała na znaczeniu w wymiarze teoretycznym i praktycznym. Upowszechniła się jako sposób ujmowania zmian w zakresie foresightu, badań nad przyszłością (futures thinking), metod scenariuszowych. Znalazła również (i przede wszyst- 
kim) liczne zastosowania praktyczne. Analiza trendów jest integralną częścią opracowywanych strategii rozwojowych przedsięwzięć gospodarczych i technologicznych, jest składnikiem strategii rozwoju organizacji. Jest ona także częścią badań użytkowników w procesach projektowych przy tworzeniu innowacyjnych rozwiązań, przy projektowaniu strategii komunikacyjnych, przy tworzeniu produktów oraz usług. Wykorzystuje się ją również przy tzw. projektowaniu społecznym. Jest wówczas składnikiem procesu projektowego i kreuje perspektywę rozumienia zmian, w jakiej powstają innowacje służące rozwiązywaniu realnych problemów społecznych ${ }^{1}$. Analiza trendów zyskała na znaczeniu w obliczu zmian emergentnych, dynamicznych, trudno przewidywalnych lub uznawanych za następstwo tzw. dzikich kart.

Dotychczasowe teoretyczne i praktyczne zastosowania analizy trendów świadczą o tym, że posiada ona potencjał opisowo-eksplanacyjny oraz znaczenie społeczne (rozwiązywanie zdiagnozowanych problemów, projektowanie rozwiązań dostosowanych do potrzeb). Jako podejście nie jest jednak szerzej i głębiej analizowana krytycznie. Tym artykułem staram się wypełnić tę lukę i wskazać kluczowe cechy tego podejścia. Łącząc je $\mathrm{z}$ hermeneutyką, przyjmuję założenie, $\dot{z} e \mathrm{w}$ analizie trendów istnieje wiele filozoficznych uwarunkowań rozumienia zmian, które warto poznać głębiej, oraz że sama analiza wymaga krytycznego namysłu nad jej znaczeniem. Śledząc rozwój jej kolejnych zastosowań, można przyjąć, że staje się istotnym narzędziem wykorzystywanym w badaniach nad przyszłością oraz służącym do przeobrażania rzeczywistości w postaci strategii rozwojowych i projektów.

Usiłując określić przydatność analizy trendów, Sarwant Singh wskazuje na globalny, znaczący, głównie makroekonomiczny charakter zmian trendowych. Według niego odnoszą się one do rozwoju gospodarki, społeczeństwa, kultury, jak również do indywidualnych doświadczeń ludzi. Kształtują przyszłość świata i wpływają na tempo zachodzących zmian oraz wskazują na ich główne czynniki sprawcze ${ }^{2}$. Na wstępie trzeba podkreślić, że nie da się ograniczyć analizy trendów wyłącznie do modelu badawczego, którego podstawę stanowi podejście empiryczne, a bezpośrednim przedmiotem są ustalone fakty. Właści-

1 T. Brown, J. Wyatt, Design Thinking for Social Innovation, „Stanford Social Innovation Review”, Winter 2010, URL: https://new-ideo-com.s3.amazonaws.com/assets/files/pdfs/news/2010_ SSIR_DesignThinking.pdf, dostęp: 8.10.2020.

2 S. Singh, New Mega Trends: Implications for our Future Lives, Palgrave Macmillan, London 2012, s. $4-5$. 
wą analizę rozpoczyna próba poszukiwania związków i możliwych konsekwencji zachodzących zmian, dlatego nie sposób praktyki badawczej ograniczać tylko do jednej dyscypliny oraz koncentrować się na przeszłości oraz teraźniejszości. Istotne dla rozumienia zmian jest to, że praktyka badawcza nie wynika wyłącznie $z$ danych dostępnych, lecz wymaga odwołań do wartości niematerialnych (intangible outputs), czyli tego, co wynika z wnioskowania, intuicji oraz metod pośrednich. W takich warunkach analiza trendów jest zwykle częścią szerszych, strategicznych analiz, przybierających postać foresightu, myślenia przyszłościowego i badań nad przyszłością ${ }^{3}$. Pod tym względem analiza w większym stopniu przypomina próby tworzenia możliwych obrazów i scenariuszy przyszłości i ich rozumienia niż budowanie teorii naukowej zorientowanej na cele stricte poznawcze: poszukiwanie prawidłowości, formułowanie praw, budowanie teorii opisywanych zjawisk i procesów. Wskazuję je jako jeden z możliwych celów, bez intencji ograniczania nauki do wybranego modelu czy rozważania kwestii jej historycznego rozwoju i koncepcyjnego zróżnicowania.

\section{Inter- i transdyscyplinarność analizy trendów}

Badania skoncentrowane na analizie zmian są jednym z kluczowych sposobów postępowania rozpowszechnionego w nauce i w związanych $\mathrm{z}$ nią dziedzinach życia. Powszechnie przyjmuje się, że umiejętność rozumienia dokonujących się procesów decyduje o znajomości rzeczywistości oraz o wynikających z tego możliwościach działania, polegającego na abstrakcyjnie pojętym tworzeniu, przekształcaniu czy odtwarzaniu.

Analiza trendów ma obecnie kilka postaci i w każdym przypadku lokuje się na ścieżce inter- oraz transdyscyplinarnej. Na użytek rozważań nie traktuję tych podejść alternatywnie, nie wikłam się również w szeroko komentowane spory o sens i konsekwencje każdej z tych postaw badawczych ${ }^{4}$. Zależy mi głównie na

J. Voros, A Generic Foresight Process Framework, „Foresight” 2005, Vol. 5, No. 3, s. 11, doi:10.1108/14636680310698379.

4 Por. M. Kita, „Razem”: konsiliencja, interdyscyplinarność, transdyscyplinarność, w: Transdyscyplinarność badań nad komunikacja medialna, t. 1: Stan wiedzy i postulaty badawcze, red. M. Kita, M. Ślawska, Wydawnictwo Uniwersytetu Śląskiego, Katowice 2012, URL: https://rebus.us.edu. pl/bitstream/20.500.12128/2543/1/Kita_\%20Razem_konsiliencja_interdyscyplinarnosc_transdyscyplinarnosc.pdf, dostęp: 3.07.2019; Interdyscyplinarnie o interdyscyplinarności. Między idea a praktyka, red. A. Chmielewski, M. Dudzikowa, A. Grobler, Oficyna Wydawnicza „Impuls”, 
tym, by wyjaśnić, w jaki sposób w każdym z tych podejść kształtuje się interakcja między odmiennymi dyscyplinami naukowymi, jak zmienia się rozumienie przedmiotu poznania, możliwości badawcze oraz jak pojawiają się całkowicie nowe wyzwania poznawcze i interpretacyjne.

Przyjmuję, że interdyscyplinarność polega na takim podejściu w badaniach, które angażuje odmienne dyscypliny, stwarzając możliwość analizy tych samych zmian $\mathrm{z}$ wykorzystaniem odmiennych teorii i metod oraz uzyskania wyników tworzących nowe wartości poznawcze oraz nową wiedzę o badanych zjawiskach. Interdyscyplinarność zakłada współdziałanie odmiennych dyscyplin. Traktuję ją nie tylko instrumentalnie, jako specyficzne podejście badawcze, lecz także jako historycznie ugruntowane dążenie do syntezy wyników poznania naukowego w dziedzinach zdolnych do badawczej, twórczej interakcji.

Abstrahuję zarazem od interdyscyplinarności jako teoretycznego problemu z zakresu filozofii nauki i ogólnej metodologii nauk, któremu towarzyszą spory i dyskusje mające swoje własne dzieje oraz orędowników i przeciwników. Pomijam zatem kwestię ściśle teoretycznych sporów o interdyscyplinarność - powstają one w sposób nieuchronny jako wynik analizy i krytyki osiągnięć badawczych, rodzących się w rezultacie interakcji odmiennych dziedzin wiedzy.

Sądzę, że trudnym do zakwestionowania osiągnięciem interdyscyplinarności jako praktyki badawczej jest możliwość uchwycenia złożoności analizowanych zjawisk oraz tworzenia komplementarnego obrazu analizowanych zmian. To podejście nie jest wolne od wad, wymaga bowiem syntezy wiedzy z zakresu dyscyplin, które osiągnęły autonomię poznawczą oraz historyczne ugruntowanie, a zatem określiły przedmiot, ukształtowały swój język, metodę i instrumenty badawcze, sformułowały podstawy teoretyczne i określiły swoje miejsce w strukturze poznania. Wszystkie one wyznaczają tożsamość dyscyplin, mogą zatem ograniczać interakcję uwarunkowaną czynnikami społecznymi, kulturowymi czy politycznymi, a w dalszej kolejności wpływającymi na ostateczną postać interdyscyplinarności ${ }^{5}$.

Kraków 2012; Głosy w sprawie interdyscyplinarności. Socjologowie, filozofowie i inni o pojęciach, podejściach i swych doświadczeniach, red. J. Kurczewska, M. Lejzerowicz, Wydawnictwo IFiS PAN, Warszawa 2014.

5 J. Kurczewska, Wariacje na temat interdyscyplinarności, w: Oceny nauki, red. Sz. Biliński, Polska Akademia Umiejętności, Kraków 2014, s. 81, URL: http://pau.krakow.pl/Debaty_PAU/T_I/Debaty_PAU_I_dyskusja_Kurczewska.pdf, dostęp: 08.07.2019. 
Z kolei transdyscyplinarność traktuję jako etap w rozwoju badań i możliwość współdziałania dyscyplin tradycyjnie uchodzących za autonomiczne, a jednocześnie za otwarte poznawczo i zdolne do zwrotów badawczych. Owe zwroty mogą wynikać z pojawiających się potrzeb, doświadczeń i możliwości uczestników i beneficjentów badań. Ich efektem jest świadome przekraczanie granic dyscyplinarnych na rzecz nowych sposobów poznania, nowych metod badawczych, nowych podejść teoretycznych oraz nowych rozstrzygnięć mających znaczenie praktyczne. Zmiany łączą się wówczas z podejściem pozwalającym zarówno określić i zrozumieć rzeczywiste i formalne ograniczenia, jak i poszukiwać sposobów ich przekraczania ${ }^{6}$. Rozwój dyscyplin, polegający na przedmiotowej i metodologicznej transgresji, na poszukiwaniu możliwości uwalniania się od istniejących wzorców oraz kooperowania $z$ innymi dyscyplinami, jest jednym z czynników przeobrażeń nauki oraz - co w tym przypadku ważniejsze - pozwala w kontekstowy i zmienny sposób analizować obserwowane zmiany, szczególnie wtedy, gdy nie są przedmiotem zainteresowania tylko jednej dyscypliny. W transdyscyplinarność wpisuje się idea interpretatywnego podejścia badawczego oraz poszukiwania nowych możliwości wykorzystania osiągniętej wiedzy? Jeszcze jednym i ważnym jej wyznacznikiem jest nieuchronne przesuwanie się granic poszczególnych dyscyplin oraz podejmowanie nowych problemów, takich, jakie dotąd nie pojawiały się na gruncie poszczególnych nauk ${ }^{8}$.

Analiza trendów jest w humanistyce podejściem badawczym o stosunkowo niewielkim zaawansowaniu teoretycznym ${ }^{9}$. Odmienne doświadczenia $w$ tym zakresie mają ekonomiści, głównie za sprawą modeli, metod i narzędzi analizy

Zob. M. Kita, dz. cyt., s. 19 i nn.

R. Rorty, Intelektualista humanistyczny: jedenaście tez, w: tegoż, Filozofia a nadzieja na lepsze społeczeństwo, tłum. S. Tokariew, Wydawnictwo Naukowe Uniwersytetu Mikołaja Kopernika, Toruń 2013.

8 J. Tabaszewska, „Wędrujące pojęcia”. Koncepcja Mieke Bal - przykład inter- czy transdyscyplinarności?, „Studia Europaea Gnesnensia” 2013, nr 8, s. 113-130, URL: http:// bazhum.muzhp.pl/media//files/Studia_Europaea_Gnesnensia/Studia_Europaea_Gnesnensia-r2013-t8/Studia_Europaea_Gnesnensia-r2013-t8-s113-130/Studia_Europaea_Gnesnensia-r2013-t8-s113-130.pdf, dostęp: 12.07.2019; J. Bernstein, Transdisciplinarity: A Review of Its Origins, Development, and Current Issues, „Journal of Research Practice” 2015, Vol. 11, Issue 1, URL: http://jrp.icaap.org/index.php/jrp/article/view/510/436, dostęp: 12.07.2019.

9 Por. J. Pieriegud, Wykorzystanie megatrendów do analizy przyszłościowego rozwoju sektorów gospodarki, w: Megatrendy i ich wpływ na rozwój sektorów infrastrukturalnych, red. J. Gajewski, W. Paprocki, J. Pieriegud, Instytut Badań nad Gospodarką Rynkową - Gdańska Akademia Bankowa, Gdańsk 2015, s. 13-20. 
statystycznej. Analizę trendów w naukach ekonomicznych zdominowały metody ilościowe. Analiza trendów społecznych, kulturowych, technologicznych i środowiskowych poszerza je o metody jakościowe. Analizie tej nie towarzyszy wypracowana historycznie, jednolita i rozpowszechniona metodologia ani szeroka teoretyczna podbudowa, duże znaczenie ma za to możliwość łączenia potencjałów poznawczych wielu dyscyplin. Uzasadnieniem jest to, że zmiany przybierające postać trendów mają zwykle charakter złożony (są np. ujmowane jako sieciowe oraz jako mieszane, występujące w kilku dziedzinach rzeczywistości jednocześnie), wymagają zatem badań prowadzonych z wielu perspektyw oraz wykorzystania kilku metod jednocześnie, np. triangulacji. Innym, równie istotnym wyróżnikiem analizy trendów jest to, że zwykle podejmuje się ją w kontekście zadań praktycznych, a więc nie tyle w imię celów wyłącznie teoretycznych, ile dla stworzenia podstaw do dalszych działań, np. projektowania przyszłych zmian w związku z określonym procesem lub zadaniem ${ }^{10}$.

Analizy trendów generują wiedzę o zmianach pozwalającą rozpoznawać złożoność badanych zjawisk, szczególnie wtedy, gdy odnoszą się one do kilku różnych dziedzin rzeczywistości i wymagają możliwie szerokiego podejścia, pozwalającego na odzwierciedlenie sieciowych zależności tychże zmian. Przykładem obrazującym tę sytuację może być trend, jakim jest starzenie się społeczeństwa. Jego analiza wymaga podejścia znamiennego zarazem dla demografii, socjologii, ekonomii, kultury i technologii. By kompleksowo poznać i zrozumieć charakter zjawiska, niezbędne są zarówno badania podstawowe, jak i próba zmierzenia się z wyzwaniami wynikającymi ze zmiany jakościowej pojawiającej się wraz z przeobrażeniami struktury wiekowej społeczeństwa. Analiza trendu służy wyjaśnieniu samej zmiany oraz warunkuje działania związane z jej znaczeniem i możliwymi konsekwencjami (por. raporty Future of an Ageing Popoulation, 2016; World Population Ageing, 2017; The 2018 Ageing Report Underlying Assumptions \& Projection Methodologies, 2017).

Innym przykładem transdyscyplinarnej interpretacji zjawisk jest podejście ekonomii behawioralnej, łączące kwestię psychicznych uwarunkowań indywidualnych decyzji, mechanizmów zachowań społecznych oraz ekonomicznych konsekwencji działań podejmowanych przez ludzi jako konsumentów ${ }^{11}$. W tym in-

10 Praktycznie zorientowane podejście analityczne prezentuje praca A.L. Kjaer, The Trend Management Toolkit. A Practical Guide to the Future, Palgrave Macmillan, London 2014, s. 55 i nn.

11 R.H. Thaler, Zachowania niepoprawne. Tworzenie ekonomii behawioralnej, tłum. J. Konieczny, Wydawnictwo Media Rodzina, Poznań 2018. 
terdyscyplinarnym modelu wyjaśniania Richard Thaler, nawiązując do Daniela Kahnemana i Amosa Tversky’ego, usiłował „odkodować” i zinterpretować wiele zjawisk ekonomicznych z perspektywy wewnętrznych doświadczeń i decyzji ludzi. Wykazywał przy tym, że racjonalność zachowań ma ograniczony charakter lub w nikłym stopniu poddają się interpretacji przy użyciu teorii racjonalnego wyboru i klasycznych teorii ekonomicznych ${ }^{12}$.

\section{Analiza trendów - poziom i zakres badań}

Analiza trendów jako forma badań zmian pełni kilka funkcji: opisową, nomotetyczną oraz narracyjną. W tym ujęciu jest ona sensotwórczym, a zarazem istotnym poznawczo oraz zróżnicowanym funkcjonalnie ustalaniem i interpretowaniem badanych zmian. Jego wynikiem jest kategoryzacja i opis zmian obserwowanych (faktycznych) oraz możliwych, a także poszukiwanie logiki zachodzących procesów, wskazywanie więc uniwersalnych czynników i następstw rozwoju, wyszukiwanie korelacji między pozornie całkowicie niezależnymi od siebie zjawiskami ${ }^{13}$. Trzecia funkcja - narracyjna - polega na dążeniu do stworzenia szerszego i sensownego obrazu przemian możliwych, przyszłościowych. Jej znaczenie wyraża się w kontekstowym rozumieniu zachodzących procesów, łączeniu ich z praktykami życiowymi w sferze potrzeb, zachowań, relacji.

Częścią analizy trendów jest wartościowanie badanych przemian. W wymiarze aksjologicznym chodzi więc o próbę nadawania wartości badanym zmianom, o ich hierarchizowanie oraz o określanie znaczenia, zasięgu i sposobu oddziaływania. Trend jako kategoria opisowo-aksjologiczna pozwala łączyć ze sobą odrębne dziedziny rzeczywistości i dokonujące się w nich zmiany, wskazuje na sposoby ich przenikania się oraz określa ich możliwe znaczenie ${ }^{14}$.

Trend nie jest jedynie abstrakcyjną kategorią analizy teoretycznej. W praktyce wskazuje na możliwości zmian, a w węższym zakresie określa potrzeby, postawy,

12 D. Kahneman, Pułapki myślenia. O myśleniu szybkim i wolnym, tłum. P. Szymczak, Wydawnictwo Media Rodzina, Poznań 2012.

13 Zob. A. Kucner, Aksjologiczne i ontologiczne aspekty trendów, w: A. Kucner, G. Pacewicz, A. Rutkowska, R. Sierocki, J. Sobota, M. Sternicka-Kowalska, R. Szulc, M. Świgoń, P. Wasyluk, Trendy. Interpretacje i konfrontacje, Instytut Filozofii UWM w Olsztynie, Olsztyn 2018, s. 194, URL: http://wmbc.olsztyn.pl/Content/5521/Trendy_Interpretacje\%20i\%20konfrontacje-min. pdf, dostęp: 22.07.2019.

14 Tamże, s. 138. 
wybory jednostek i grup społecznych, pozwala rozumieć oczekiwania, podejmowane decyzje i zachowania ludzi, określa istniejące ryzyka. W szerszym zakresie określa sens zagregowanych zmian społecznych, środowiskowych, kulturowych, technologicznych, ekonomicznych i politycznych. Takie podejście wymaga zarówno uznania złożoności badanych zjawisk, jak i możliwości zastosowania odmiennych ujęć interpretacyjnych, wynikających ze specyfiki poszczególnych dyscyplin ${ }^{15}$.

Ostateczny charakter analizy trendów determinuje jej cel oraz miejsce w ogólnej strukturze badań. Analiza może mieć charakter autonomiczny, może być również częścią szerszych praktyk badawczych i projektowych. W pierwszym przypadku polega ona na dążeniu do uchwycenia dominujących tendencji wśród obserwowanych zmian i ich interpretacji, czyli określeniu znaczenia, kierunku, dynamiki, trwałości procesów. Drugi przypadek odnosi się do badań foresightowych oraz myślenia przyszłościowego, w których analiza trendów stanowi jedną z części procesu badawczego i służy celom praktycznym. Dla analizy trendów istotna jest możliwość równoczesnego uchwycenia wpływu, jak i znaczenia obserwowanych zmian na różnych poziomach abstrakcji. Rozpoznanie trendu - według Martina Raymonda - może polegać np. na uchwyceniu jego emocjonalnego, intelektualnego i duchowego znaczenia, a więc tego, co decyduje o sile i skali oddziaływania ${ }^{16}$. Analiza trendów może być próbą interpretacji zmian i służyć opracowaniu strategii rozwojowych, scenariuszy przyszłości, jest więc zorientowana na określanie oraz realizację praktycznych celów. Analiza może również stanowić część szerszego procesu, np. planowania strategii, wdrażania planów lub koncepcji rozwoju czy różnego rodzaju audytów dedykowanych innym celom. W dalszej kolejności może służyć organizacji działań marketingowych, budowaniu wizerunku czy komunikacji z odbiorcami dóbr i usług. Efektem staje się ostatecznie mniej lub bardziej spójna wizja przyszłości, wyróżniona przewodnią ideą lub zbiorem charakterystycznych rozwiązańn ${ }^{17}$.

15 Przykładem takiego interdyscyplinarnego podejścia do analizy i interpretacji zmian jest mający wiele odmian model STEEP, znajdujący praktyczne zastosowań w ekonomii, naukach o zarządzaniu, foresighcie. Zob. A. Hines, P. Bishop, Thinking about the Future: Guidelines for Strategic Foresight, Hinesight, Houston 2015, s. 130 i nn.

16 M. Raymond, The Trend Forecaster's Handbook, Laurence King Publishing, London 2010, s. 14.

17 Por. A. Stasik, Narracje o przyszłości a projektowanie innowacji-perspektywa studiów nad nauka i technologia, „Stan Rzeczy” 2018, nr 1(14), s. 163-164. 
Dotychczasowa praktyka badawcza wskazuje na to, że pod jednym wspólnym określeniem analizy trendów występują niekiedy odległe od siebie sposoby badania procesów i wykorzystania ich rezultatów. Singh przez „megatrendy” rozumie - ze względu na ich zagregowany, wielkoskalowy charakter - globalne, trwałe, makroekonomiczne czynniki rozwojowe (macroeconomics forces), które oddziałują na sferę biznesu, gospodarki, społeczeństwa, kultury oraz na jednostkowe doświadczenia ludzi, by „tym samym - jak pisze - określić nasz przyszły świat i jego wzrastające tempo zmian”. Megatrendy wyróżniają zatem globalna skala, trwałość czynników przemian oraz złożone oddziaływanie na wiele równoległych dziedzin życia ${ }^{18}$. Znaczenie megatrendów Singh przyrównuje do Newtonowskich zasad dynamiki, wskazując na stałość wpływu megatrendów na zachodzące zmiany oraz konstatując, że szybkość i skala wpływu megatrendów jest wprost proporcjonalna do globalnych sił, które na nie oddziałują. Przyjmuje również, że każdemu megatrendowi towarzyszy równie silna i przeciwnie skierowana reakcja ${ }^{19}$. Warto dodać, że takie ujęcie jest równoznaczne z najszerszą interpretacją procesów przemian, lecz nie wyczerpuje możliwych sposobów rozumienia trendów i zasięgu ich analizy. Odwołuję się jednak do niego, gdyż pozwala na jednostronne określenie granicy rozważań ze względu na swoistą perspektywę interpretacji zmian. Oznacza to, że skala mega jest zewnętrzną granicą ich rozumienia i że w praktyce nie podejmuje się bardziej abstrakcyjnych badań w tym zakresie. Równie istotne jest wówczas przyjęcie założenia, że każdy inny poziom analizy trendów jest tworzeniem kolejnych, paralelnych, nierzadko krzyżujących się ścieżek rozumienia.

W zupełnie innym kierunku idzie interpretacja przywoływanego wcześniej Raymonda, który nawiązując do Dawkinsowskiej koncepcji samolubnego genu (memu), stara się tłumaczyć fenomen trendów i wywoływanych nimi zachowań z perspektywy biologii ewolucyjnej ${ }^{20}$. Według Raymonda, trendy - na wzór memów - mają ścisły związek z mechanizmami przystosowania się organizmów do zmieniających się warunków życia. W takiej narracji znaczenie memu przejawia się w różnorodnych formach wpływu na indywidualne i społeczne wybory oraz zachowania. Tego rodzaju determinacja nie jest zupełnie świadomym działaniem. Jest uwarunkowana pierwotnym, głęboko zakorzenionym mechanizmem,

\footnotetext{
$18 \quad$ S. Singh, dz. cyt., s. 4.

19 Tamże, s. 226.

20 R. Dawkins, Samolubny gen, tłum. M. Skoneczny, Pruszyński i Spółka, Warszawa 2012.
} 
który można rozumieć i któremu można jednocześnie podlegać. Rozprzestrzenianie się trendu jest - według porównania Raymonda - jak niekontrolowana epidemia wirusów ${ }^{21}$.

Innym czynnikiem, wskazywanym przez niego i mającym znaczenie $\mathrm{w}$ rozpowszechnianiu się trendów, są innowacje. Odwołuje się on do znanej koncepcji dyfuzji innowacji Everetta Rogersa ${ }^{22}$ i w sześciu opisywanych etapach dostrzega analogie pozwalające rozumieć logikę procesu rozpowszechniania się trendów jako zjawisk obejmujących kulturę, technologię, życie społeczne, gospodarkę oraz czynniki środowiskowe ${ }^{23}$.

Przywołane powyżej przykłady interpretacji trendów na podstawie reguły per analogiam (w powiązaniu z mechaniką Newtonowską, Dawkinsowską koncepcją samolubnego genu czy Rogersowską koncepcją dyfuzji innowacji) świadczą o tym, że nie istnieją jednoznacznie sformułowane i rozpowszechnione wzorce rozumienia zmian trendowych, a ich łączenie z różnorodnymi konceptami pokazuje spory potencjał interpretacyjny, choć nie zawsze świadczy on o dużych możliwościach eksplikacyjnych, jakich można by oczekiwać od teorii nomotetycznych, takimi bowiem nie są. Istotniejsze dla analizy trendów jest dążenie do nadania znaczenia aktualnym i przyszłym zmianom niż teoretyzowanie. $\mathrm{W}$ analizach trendów, prowadzonych z perspektywy różnych dyscyplin nauki, mieszają się odmienne wzorce i tradycje badawcze. Przykładem mogą być nauki ekonomiczne oraz demografia, w których analizy trendów bazują na metodach ilościowych (głównie statystycznych) oraz polegają przede wszystkim na kwantyfikacji zmian. $\mathrm{Z}$ kolei analizy istotne $\mathrm{z}$ kulturowego punktu widzenia są prowadzone głównie na podstawie metod jakościowych.

Zmienność perspektyw i kontekstowość badań wskazuje na szerokie możliwości analizowania trendów, uzmysławia zarazem, że trend jako sposób interpretacji zmian nie odnosi się jedynie do zjawisk odkrywanych na podstawie obserwacji, lecz w równym stopniu polega na konceptualizacji różnorodnych danych. Innymi słowy, w analizie trendów zbiegają się dwa podejścia: jedno - typowe dla metodologii empirycznej, rejestrujące i generalizujące; drugie - charakterystyczne dla myślenia hermeneutycznego, które polega na określaniu znaczenia zmian na podstawie ich rozumienia, ten zaś proces przekracza wyłącznie obser-

$21 \quad$ M. Raymond, dz. cyt., s. 15-17.

22 Por. E. Rogers, Diffusion of Innovations, The Free Press, New York, London 1983, s. 247 i nn.

23 J. Mikołajec, Dwa typy dyfuzji innowacji i ich ontologiczne założenia, „Zeszyty Naukowe Politechniki Śląskiej” 2014, z. 72, s. 128. 
wowalne dane. Jego istotnym elementem jest przedrozumienie, zawierające ogół czynników wyznaczających sposób podejścia do badań, np. kontekst kulturowy, gospodarczy, społeczny, konsumpcyjny, etyczny, a także idee orientujące kierunek rozumienia, jak np. zrównoważony rozwój lub cyrkularnośćc ${ }^{4}$. Istotna dla nich jest wszelka wcześniejsza wiedza, wyobrażenia i doświadczenia, stanowią one bowiem płaszczyznę i punkt odniesienia podejmowanych analiz. Analiza trendów nie jest więc ani bezzałożeniowa, ani stricte faktograficzna. Jej orientację określają przyszłe, możliwe, oczekiwane efekty zmian, których nie sposób jednoznacznie przewidzieć, dlatego analiza nie jest prognozowaniem w ścisłym znaczeniu, nie polega na tworzeniu jednego tylko scenariusza przyszłości, nie ogranicza się do jednej wykładni ani jednej perspektywy rozważań.

Uwzględniając zasięg i trwałość badanych zmian, w analizie trendów da się wyodrębnić kilka poziomów - obok wspominanej wcześniej analizy megatrendów, rozróżnia się analizę makro- oraz mikrotrendów ${ }^{25}$. Stopniowe zawężanie perspektywy badawczej pozwala wprawdzie na wnikliwsze i głębsze analizy, lecz jednocześnie odnosi się do coraz mniejszego zasięgu oraz krótszych okresów zmian, sprawiając, że w praktyce powstająca interpretacja tłumaczy tylko wybrane procesy i nie aspiruje do takich wartości jako powszechność czy - tym bardziej - konieczność. Zmienia ono również kontekst i znaczenie analizowanych procesów. Trzeba dodać, że tego rodzaju trójstopniowy podział ma charakter czysto instrumentalny, istotniejsza od niego wydaje się logika podejmowanych analiz. O sytuacji, w której interpretowanie zmian polega na analizie trendów, Hans Rosling i Mattias Horx twierdzą, że jest wyrazem posybilizmu, a więc takiej postawy, która koncentruje się na ustalaniu i wskazywaniu możliwości i która wyraża się w poszukiwaniu kompromisu między tym, co nieuniknione, nieuchronne a tym, co możliwe do zaplanowania i stworzenia ${ }^{26}$. O ile posybilizm w obecnych realiach może być traktowany przez analityków przyszłości jako reakcja na rzeczywistość ujmowaną w formule VUCA (volatility, uncertainty, complexity, ambiguity ${ }^{27}$ ), o tyle z filozoficznego punktu widzenia można przyjąć, że

24 Trend and Future of Sustainable Development, eds. H. Lakkala, J. Vehmas, Finland Futures Research Centre, Helsinki 2011.

25 Por. C. Durst, M. Durst, M. Saffer, Weak Signals, Hypes or Trends - Identify Innovation Opportunities and stay ahead of your Game, 2017, s. 5, doi: 10.13140/RG.2.2.27409.02408.

26 M. Horx, 13-Future Trends. Zwei neue Trendbegriffe für 2018, URL: https://www.horx.com/ future-trends/, dostęp: 11.02.2019.

27 Por. np. The VUCA Report, The Strategic Agility Institute, 2016, URL: https://static1.squarespace.com/static/5579c941e4b00a23147233ce/t/56eff7f420c6474a7cd617ab/1458567164889/ 
jest to pewien sposób uprawiania ontologii jako namysłu nad tym, co możliwe, oraz jako jednej z możliwych postaci analizy zmian.

$Z$ analizy trendów nie wyłania się spójny, jednoznacznie uporządkowany obraz zmian. Jej wyniki nie stanowią teorii „z jednej bryły”. Są natomiast próbą porządkowania, łączenia oraz wskazywania wpływu poszczególnych czynników zmian na wybrane sfery ludzkiej aktywności. Analizę trendów należy traktować jako kontekstowe i wielopoziomowe podejście badawcze i interpretacyjne, skoncentrowane głownie na rozumieniu rzeczywistych oraz możliwych zmian, a w dalszej kolejności na praktycznym wykorzystaniu tej wiedzy.

\section{Hermeneutyczna perspektywa rozumienia trendów}

W dotychczasowych rozważaniach kilkakrotnie wskazywałem na rozumienie zmian jako jeden $z$ ważniejszych celów analizy trendów. Ów cel nie jest jedynie teoretycznym wyzwaniem analityków, lecz wysiłkiem mającym znaczenie społeczne, ekonomiczne, kulturowe i aksjologiczne, które odzwierciedla się w motywach, wyborach i działaniach ludzi. Pojęciem „rozumienia” określam wszelkie wysiłki poznawcze oraz interpretacyjne zmierzające do uczynienia obserwowanych oraz możliwych procesów zmian sensownymi, a więc takimi, gdy możliwe staje się wskazanie ich znaczenia, charakteru i konsekwencji. Analiza trendów jest zorientowana na przyszłość, nie jest jednak wyłącznie spekulatywnym sposobem odnoszenia się do niej, a próbą jej tłumaczenia na podstawie tego, co się wydarzyło, tego, co się dzieje, oraz tego, co wydaje się możliwe. Trudno lokować ją wśród podejść typowo futurologicznych, jak również redukować do roli archeologii przyszłości.

Odwołanie do hermeneutyki jako metody tłumaczenia egzystencji i wytworów człowieka, której dwoma istotnymi analitycznie składnikami są przedrozumienie (uprzedzenia) i rozumienie, powiązane postępującą, wzajemnie uwarunkowaną i nieodwracalną zmianą każdego z nich, pozwala spojrzeć na trendy jako możliwy przedmiot takiego podejścia ${ }^{28}$. Trudno je zredukować do wymiaru czysto poznawczego, jak również problematyczne może się wydawać ogranicze-

The_VUCA_Report_1.1_March_2016.pdf, dostęp: 22.02.2019.

28 H.-G. Gadamer, Prawda i metoda. Zarys hermeneutyki filozoficznej, tłum. B. Baran, Wydawnictwo Naukowe PWN, Warszawa 2004, s. 382. 
nie jego znaczenia wyłącznie do ważnej egzystencjalnie funkcji sensotwórczej. Przedrozumienie pełni rolę ukierunkowującą i syntezującą, zawiera istotne reguły, formy i sposoby rozumienia, zarówno te istotne logicznie i językowo, jak również kulturowe i społeczne. „Uchwytująca całość antycypacja sensu - jak pisał Gadamer - staje się wyraźnym zrozumieniem dzięki temu, że części, określające się na podstawie całości, ze swej strony określają tę całość"29. Uzupełnieniem form rozumienia są wartości, pozwalające określać znaczenie poszczególnych trendów (w dalszych rozważaniach świadomie pomijam spory powstałe wokół kluczowych kwestii aksjologicznych, nie mają bowiem w tym miejscu istotnego znaczenia). Innymi słowy, w przedrozumieniu zawarte są osadzone w przeszłości warunki rozumienia przyszłości, opisywanej z perspektywy trendów jako zmian. Są one zarówno transcendentalne - zawarte w świadomości jako warunki wszelkiej refleksji, a więc niezależne od zewnętrznej obiektywnej rzeczywistości (faktów), jak również realne - związane z tym, co obserwowane, doświadczane, istniejące poza granicami świadomości. Obok nich szczególną sferę stanowią przeżycia i doświadczenia indywidualne oraz społeczne interakcje, jako to, w czym ujawniają się trendy. Warto dodać, że już samo odwołanie do trendu jako formy zmiany jest interpretacją, a więc określonym sposobem jej rozumienia, takim, w którym istotne jest zarówno to, co się wydarza, jak i to, jak może być pojmowane, doświadczane i oceniane.

W pracy Hermeneutyczny zwrot filozofii Andrzej Przyłębski na podstawie obszernych analiz historyczno-filozoficznych sformułował kluczowe tezy własnego ujęcia paradygmatu filozofii hermeneutycznej ${ }^{30}$. Ich konfrontacja ze zorientowanymi na przyszłość analizami trendów pozwala na wniosek, że w tego rodzaju podejściu ujawnia się wiele zbieżności z hermeneutycznym wzorcem myślenia.

Tamże, s. 400.

30 A. Przyłębski, Hermeneutyczny zwrot filozofii, Wydawnictwo Naukowe UAM, Poznań 2005, s. 242-244. Odwołuję się do tej próby koncepcyjnego ujęcia paradygmatu filozofii hermeneutycznej ze względu na jej syntetyczny charakter i ze względu na przystawalność tego podejścia do analizy trendów jako dążenia do interpretacji i rozumienia dokonujących się zmian. Jednocześnie mam świadomość, że wykorzystywany tu paradygmat jest jedną z wielu możliwości ujęcia hermeneutyki, jej przedmiotu, zadań i znaczenia, a nie jedyną i uniwersalną jej wykładnią. Warto dodać, że próba powiązania analizy trendów z myśleniem hermeneutycznym wywołuje skojarzenia $\mathrm{z}$ wyzwaniami, które $\mathrm{z}$ hermeneutyką jako formułą metodologiczną humanistyki formułował na początku ubiegłego stulecia Wilhelm Dilthey, z zastrzeżeniem jednak, że nie dzieje, lecz przyszłość wyznacza przedmiot analizy trendów i dążenia do zrozumienia zmian. Zob. J. Grondin, Wprowadzenie do hermeneutyki filozoficznej, Wydawnictwo WAM, Kraków 2007, s. 109 i nn. 
Sens analizowania trendów wynika z dążenia do nadania zróżnicowanym przejawom zmian możliwie spójnej i zrozumiałej postaci. Kluczowy cel nie jest tu epistemologiczny, lecz praktyczny i egzystencjalny, odnosi się bowiem do różnorodnych sposobów bycia człowieka w świecie. Analiza trendów służy rozumieniu i wartościowaniu zmian. Wyróżnia ją również to, że przekracza ona czysto historyczne ramy myślenia, nie polega bowiem na ekstrapolacyjnym przenoszeniu minionych doświadczeń i sposobów ich rozumienia w sferę przyszłości, lecz określa znaczenie ludzkiego życia w kontekście możliwości przyszłości (np. w postaci jej scenariuszy). Istotniejsze w dążeniu do zrozumienia przyszłości wydaje się nawet przekroczenie historycznych wzorców i sposobów myślenia i w tym sensie można traktować hermeneutykę jako podejście, które „optymalizuje szanse przetrwania, wzrostu i rozwoju" ${ }^{31}$.

Analiza trendów nie aspiruje do miana wiedzy pewnej i powszechnie ważnej w sensie kantowskim. Istotniejszy jest dla niej kontekst oraz perspektywa, w jakich podejmuje się wysiłek analizowania zjawisk niż spekulatywne wnioskowanie na podstawie apriorycznych reguł myślenia w celu osiągnięcia poznania syntetycznego a priori. Kontekstowość i perspektywiczność - znamienne dla myślenia hermeneutycznego - ujawniają się również w praktycznym wykorzystaniu interpretacji przyszłości. Jest ona wynikiem założeń oraz odwołań do istniejącego rozumienia, a jednocześnie jej znaczenie kształtuje się w określonych realiach społecznych, kulturowych i technologicznych ${ }^{32}$. Podstawą wszelkich analiz jest język, a jego uwarunkowania oraz otwarty charakter przesądzają o sposobach rozumienia zmian i możliwościach partycypacji człowieka w tym, co się wydarza. Celem analiz jest istotne egzystencjalnie uczynienie świata zrozumiałym i przystępnym dla człowieka, zarazem jednak sposobem osiągnięcia tego celu nie jest tworzenie jakichkolwiek normatywnych systemów. Analiza jako podejścia tłumaczącego zmiany polega na tym, że „wnosi jedynie świadomość do sytuacji, w której się wszyscy znajdujemy, powiększając zawsze skończony i ograniczony obszar naszej wolności" ${ }^{\prime 3}$.

Przemiany wzorców i sposobów myślenia o przyszłości wskazują na to, że nie sposób uczynić jej przedmiotem ani jednoznacznej, ani wyłącznie statystycznej interpretacji. Rozumienie zmian jest otwartym poznawczo oraz - co warto pod-

\footnotetext{
$31 \quad$ A. Przyłębski, dz. cyt., s. 242.

32 V. Smil, Global Catastrophes and Trends. The Next 50 Years, The MIT Press, Cambridge, London 2012, s. 4 i nn.

33 A. Przyłębski, dz. cyt., s. 244.
} 
kreślić - zorientowanym praktycznie wykorzystaniem osiągniętego doświadczenia $w$ celu nadania znaczenia zmianom już rozpoznanym oraz możliwym. W takim podejściu ujawnia się zarówno ogół uwarunkowań rozumienia (indywidualnych, społecznych, kulturowych, technologicznych), jak i potrzeba interi transdyscyplinarnego spojrzenia na dokonujące się zmiany. Ich rozumienie jest wówczas efektem prób interpretacji oraz rekomendacji ściśle związanych z poszczególnymi dziedzinami życia, a w dalszej kolejności podejścia praktycznego (np. projektowego), wynikającego $\mathrm{z}$ rozpoznanych zmian ${ }^{34}$.

Analizy trendów są osadzone w badaniach międzykulturowych i mają charakter triangulacyjny. Sygnalizując w tym miejscu złożony problem badawczy, ograniczę się do charakterystyki kwestii. To podejście można tłumaczyć łączeniem metod umożliwiających poznanie, doświadczenie, zrozumienie zmian i zjawisk oraz partycypację. Metody mogą mieć charakter zarówno ilościowy, jak i jakościowy, a ich uzupełnieniem są praktyka i doświadczenia, w których obok łączenia różnych metod $^{35}$, na wzór etnometodologii właściwie nie rozdziela się roli badacza oraz aktywnego uczestnika badanych procesów ${ }^{36}$. Pozwala to na równoczesne śledzenie zmian oraz wzajemną walidację i rozumienie sposobów działania, ich wynikiem zaś jest uchwycenie zjawisk w ich złożoności oraz komplementarność doświadczeń i praktyki badawczej ${ }^{37}$. Obejmuje ona wszelkie możliwe sposoby obserwowania, mapowania, dokumentowania danych i łączenia ich w dalszej kolejności $z$ analizą i kluczowymi sygnałami zmian, by ostatecznie stały się podstawą wniosków $\mathrm{z}$ analizy. Triangulację traktuję tu jako efekt poszukiwania i tworzenia strategii badawczej, w której trendy poddają się zarówno ujęciu ilościowemu, jak i pogłębionej analizie jakościowej. Warto zastrzec, że triangulacji towarzyszą spory metodologiczne, wynikają bowiem z praktyki łączenia wzorców badawczych, uznawanych dotąd za alternatywne i autonomiczne ${ }^{38}$.

34 Fjord Trends 2019, URL: https://trends.fjordnet.com/Trends_2019_download.pdf, dostęp: 29.07.2019. To złożone podejście prezentuje i wykorzystuje praktycznie w modelu analitycznym 4D - A.L. Kjaer, dz. cyt., s. 14-21.

35 Zob. T. Wieczorek, Triangulacja metod $w$ badaniach społecznych. „Zagadnienia Społeczne” 2014, nr 1(1), s. 15 i nn., URL: http://czasopismo.nwsp.pl/01\%20TWieczorek\%20Triangulacja\%20metod\%20w\%20badaniach_1(1)\%202014.pdf, dostęp: 5.08.2019.

36 Por. Z. Skalska, New Normal. Trendbook 2019/2020, Nederlanse Interieur Instituut (NII), 2019; Z. Skalska, VUCA Times. Trend Book 2020/21, 360inspiration, Greenhat Innovation, 2020.

37 M. Raymond, dz. cyt., s. 122 i nn.

38 Por. E. Hornowska, A. Brzezińska, K. Kaliszewska-Czeremska, K. Appelt, J. Rawecka, A. Bujacz, Paradoksalny efekt triangulacji?, „Edukacja” 2012, nr 4(120), s. 72. 


\section{Prospekcja - praktyczny aspekt analizy}

Podejmowane przez analityków trendów próby interpretacji dokonujących się zmian zwykle nie mają charakteru stricte teoretycznego, a ich znaczenie nie polega jedynie na zaspokajaniu potrzeb poznawczych (są jedną $\mathrm{z}$ ważniejszych przesłanek działań projektowych). Analizy zmierzają do praktycznie zorientowanej prospekcji oraz łączenia jej wyników z konkretnymi przedsięwzięciami, stanowiącymi odpowiedź na dokonujące się zmiany, a niekiedy będącymi antycypowaniem przyszłych procesów. Prospekcja wymaga otwartej i innowacyjnej orientacji myślenia w podejściu projektowym ${ }^{39}$.

Analiza trendów obejmuje w istocie wiele odmiennych strategii i podejść do interpretacji zmian. Różnice między nimi wynikają głównie z przyjmowanej perspektywy, zasięgu badań oraz sposobu wykorzystania osiągniętych wyników. Jeśli analizę trendów rozumieć szeroko w sensie wielości oraz interaktywności ujmowanych procesów (np. jako sieciową analizę STEEP - czynników społecznych, technologicznych, ekonomicznych, środowiskowych oraz politycznych), a więc interdyscyplinarnie oraz długookresowo, będzie ona wyrazem poszukiwania i wskazywania globalnych możliwości rozwojowych przy pomocy analizy megatrendó $w^{40}$. W takich próbach istotne okazuje się nie tylko formułowanie ontologii przyszłości, lecz również dążenie do określenia jej wpływu na sposób rozumienia zmian zachodzących aktualnie. Innymi słowy, holistyczny namysł nad przyszłością kształtuje zarazem obraz i rozumienie teraźniejszości. Nie chodzi tu o skrajnie instrumentalne i techniczne pojmowanie analizy trendów, jak traktował ją np. Ted Gordon, współtwórca Warunkowej Analizy Trendów (Trend Impact Analysis, TIA) ${ }^{41}$, czy jak ma to miejsce w przypadku Strukturalnej Analizy Trendów (SAT), ale o umiejętność interpretowania zmian $\mathrm{w}$ podejściu jakościowym, dla którego metody i narzędzia analizy ilościowej są istotnym komponentem, jednak rozumienie zmian osiąga się na podstawie analizy wartości,

39 Z. Skalska, New Normal. Trendbook 2019/2020, dz. cyt., s. 4.

40 Najważniejsze założenia tego rozpowszechnionego podejścia rekonstruuje m.in. K. Halicka, Prospektywna analiza technologii - metodologia i procedury badawcze, Oficyna Wydawnicza Politechniki Białostockiej, Białystok 2016, s. 188.

${ }^{41}$ T.J. Gordon, Trend Impact Analysis, 1994, URL: http://www.foresight.pl/assets/downloads/publications/Gordon1994-Trendimpact.pdf, dostęp: 22.02.2019; Thinking about the Future. Guidelines Strategic Foresight, eds. A. Hines, P. Bishop, Social Technologies LLC, Houston 2015, s. 138 i nn. 
danych, indywidualnych wyborów i zachowań oraz mnogości zjawisk w sferze kultury, życia społecznego, gospodarki i technologii ${ }^{42}$. Zdania na temat ich ciągłości i przewidywalności lub ich braku są podzielone i wynikają nie tylko z tego, że każde $\mathrm{z}$ tych podejść można poprzeć stosownymi przykładami, jak robi to np. Smil ${ }^{43}$, lecz przede wszystkim są rezultatem przeciwstawnych sposobów interpretacji zmian. Te zaś okazują się być powiązane $\mathrm{z}$ historycznie osadzonymi i przeobrażającymi się wzorcami rozumienia. Powody zmienności są różne. Są one skutkiem źródeł i liczby dostępnych danych (np. big data), technologicznych sposobów gromadzenia oraz możliwości interpretacji danych (np. z wykorzystaniem sztucznej inteligencji) ${ }^{44}$. Nierzadko interpretację kauzalną wypiera i zastępuje poszukiwanie korelacji między różnymi zjawiskami, a podstawowym podejściem do rzeczywistości jest jej danetyzacja. Wykorzystanie big data zasadniczo reorientuje myślenie o przyszłości, ta bowiem ani nie jest całkowicie nieznana, ani nie jest $\mathrm{z}$ góry bezwzględnie zdeterminowana:

Nic nie jest z góry ustalone, ponieważ zawsze możemy odpowiednio zareagować na pozyskane informacje. Prognozy big data nie są ustalone raz na zawsze - mówią tylko o prawdopodobnych rezultatach, a to oznacza, że możemy je zmienić, jeśli tylko chcemy. Możemy dowiedzieć się, jak najlepiej przygotować się na nadejście przyszłości i zapanować nad nią [...]. Żeby to osiągnąć, nie będziemy musieli poznać natury wszechświata ani udowodnić istnienia bogów - wystarczy nam big data ${ }^{45}$.

Jeśli się śledzi sposoby, którymi znawcy i zwolennicy technologii jako narzędzia do zarządzania przyszłością starają się określić jej potencjał i sposoby wykorzystania, można sądzić, że w tych podejściach dominuje optyka instrumentalna, pomija się zaś szerszy kontekst następstw, ich znaczenie oraz próby formułowania spójnej wizji rozwoju ${ }^{46}$. Uwaga ta nie jest zarzutem przeciwko wartości tego podejścia. Jego znaczenie polega na możliwości zastosowania w konkretnych sy-

\footnotetext{
42 M.B. Miles, A.M. Huberman, Analiza danych jakościowych, tłum. S. Zabielski, Trans Humana Wydawnictwo Uniwersyteckie, Białystok 2000, s. 6-7.

43 V. Smil, dz. cyt., s. 71 i nn.

44 V. Mayer-Schönberg, K. Cukier, Big Data. Rewolucja, która zmieni nasze myślenie, pracę i życie, tłum. M. Głatki, MT Biznes, Warszawa 2014, s. 44 i nn.

45 Tamże, s. 149.

46 Por. K. Halicka, dz. cyt.
} 
tuacjach, wymagających precyzyjnych i skutecznych narzędzi. Stara się to zresztą pokazać autorka jednej z odmian prospektywnej analizy technologii ${ }^{47}$.

$\mathrm{Na}$ analizę trendów i możliwość jej wykorzystania można spojrzeć jeszcze inaczej, z perspektywy przemian historycznych i współczesnych form organizacji życia społecznego i gospodarczego. Zmiana paradygmatyczna w sposobie myślenia, na jaką wskazuje Jeremy Rifkin, dokonuje się między erą kapitalizmu a erą współpracy. Według niego, istnieją liczne zależności między procesami gospodarczymi i społecznymi a rozwojem technologii w sferze komunikacji, tworzenia danych i zarządzania nimi oraz źródłami energii i swobodnym dostępem do nich. Idea społeczeństwa zerowych kosztów krańcowych stanowi próbę szerokiego spojrzenia na możliwe zmiany, których uniwersalną logikę wyznaczają malejące koszty implementacji, dostępu do technologii, a w rezultacie przekształcenie wartości, postaw społecznych, metamorfoza całego systemu gospodarczego. Zmiana w sposobie myślenia polega na redefinicji kluczowych pojęć, pozwalających rozumieć zmieniającą się rzeczywistość (praca, dostęp, prosumpcja, crowdfunding, internet rzeczy, inteligentna gospodarka, zero waste, cyrkularność $)^{48}$. Każdy z tych wyznaczników zmian odpowiada trendom współtworzącym obraz przemijającej i stającej się rzeczywistości.

Rozumienie dokonujących się zmian z poznawczego i praktycznego punktu widzenia polega na nadawaniu im znaczenia. Sensmaking, będący lingwistycznym pokłosiem Wittgensteinowskiej tezy o językowym obrazie i językowej granicy świata, można uznać za sposób opisu i rozumienia trendów w każdej dziedzinie ludzkiej aktywności. Wysiłki polegające na poszukiwaniu i tworzeniu językowych form, określających dokonujące się zmiany, przybiera postać „hybrydyzacji”. Raymond wskazuje na hybrydowość jako jeden $\mathrm{z}$ aspektów interpretacji. Najogólniej rzecz biorąc, polega ona na łączeniu pojęć i nadawaniu powstałym neologizmom swoistego znaczenia, oddającego charakter pojawiających się trendów.

47 Tamże, s. 33, 50, 65.

48 Rifkin wskazuje na kilka decydujących kierunków zmian, ich wynikiem będą zaś przeobrażenia systemowe. Za decydujące uznaje rozwój internetu rzeczy, robotyzację, dostęp otwartych form edukacji, dostęp do druku 3D, prosumeryzm, nowe formy kooperacji, rozwój gospodarki współdzielenia czy głęboką biocentryczną redefinicję konsumpcji. J. Rifkin, Społeczeństwo zerowych kosztów krańcowych. Internet przedmiotów. Ekonomia współdzielenia. Zmierzch kapitali$z m u$, tłum. A. D. Kamińska, Wydawnictwo Studio EMKA, Warszawa 2016, s. 31. 
By zobrazować tego rodzaju podejście, odwołam się do kilku określeń powstałych w ten sposób takich, jak np. consumanism (conscience + consumerism) na oznaczenie świadomej konsumpcji, polegającej na wyborach towarów i usług, wynikających $z$ wiedzy o ich społecznych, etycznych czy środowiskowych następstwach. Innym przykładem hybrydy językowej opisującej zmiany jest freesumerism (free + consumerism) na oznaczenie zyskującego na znaczeniu trendu i ruchu społecznego na rzecz tych marek, towarów i usług, które są dostępne za darmo lub zawierają takie składniki. Ostatnim przykładem językowej hybrydy używanej do opisu zmian jest pojęcie womenomics (women + economics). Ma ono wskazywać na rosnącą ekonomiczną, społeczną oraz intelektualną rolę kobiet ${ }^{49}$.

Język jest kluczową sferą pozwalającą konceptualizować obserwowane zmiany, natomiast nadawanie im znaczenia jest następstwem konstruktywnego podejścia badawczego i praktycznego. Językowa perspektywa świata sprawia, że każda zmiana ostatecznie daje się sprowadzić do języka (nazwy, zdania), którego znaczenie określa granicę świata. Wymaga jednak uwzględnienia tego, co jest po drugiej stronie, czyli tego, co nie zostało nazwane i nie zyskało formy językowej. Językowe porządkowanie danych i doświadczeń jest koniecznością, jednak oczekiwanie, że w ten sposób zdołamy sformułować wszelką treść przeżyć przekracza faktyczne możliwości poznawcze i stanowi treść wiedzy apofatycznej ${ }^{50}$. Rozumienie przyszłości jest zarazem działaniem osadzonym w teraźniejszości i przeszłości, jak również projektowaniem możliwego obrazu zachodzących przemian. Wymaga zarówno odwołania do wiedzy istniejącej, jak i wskazywania jej możliwych konsekwencji.

\section{Wnioski}

Analiza trendów jest współcześnie jednym $\mathrm{z}$ wielu sposobów konceptualizowania procesów, które wpłyną na przyszłość i sposoby jej rozumienia. W tym podejściu eksponuje się szeroko rozumiane związki między zdarzeniami, zarówno te, które można ująć w postaci relacji kauzalnych, jak i te, w których stwierdza się występowanie korelacji. Obie te ścieżki interpretacji uspójniają pod względem

\footnotetext{
49 M. Raymond, dz. cyt., s. 206 i nn.

50 N.N. Taleb, Antykruchość. O rzeczach, którym służą wstrząsy, tłum. O. Siara, Kurhaus Publishing, Warszawa 2017, s. 53.
} 
metodologicznym obraz przyszłości oraz umożliwiają wskazywanie konsekwencji zmian. Jednocześnie analiza poszerza tę wiedzę o aspekt aksjologiczny i praktyczny. Integralną częścią rozumienia zmian jest ich wartościowanie i nadawanie znaczenia (wskazywanie czynników dominujących, niepowtarzalnych, nowych, unikalnych), a w dalszej kolejności określanie ich uchwytnych lub możliwych konsekwencji.

Mimo wielości i zróżnicowania podejść (ekonomicznych, socjologicznych, technologicznych czy kulturowych), analizę trendów w większym stopniu należy traktować jako projektowanie i rozumienie przyszłości niż jako prognozowanie zorientowane na wskazywanie nieuchronnych następstw rozpoznanych przyczyn. Istotny jest dla niej kontekst oraz sposób rozumienia zmian, nie zaś spełnienie rygorystycznych wymagań logiki efektywności wiedzy o badanych procesach (pewność, powszechność, niezawodność). Analizy trendów nie aspirują do rangi jednoznacznej interpretacji zmian, choć w podejściu, jakim posługują się ekonomiści (analizy to m.in. element badań foresightowych i myślenia przyszłościowego - futures thinking), są metodologicznie rozwinięte i rozpowszechnione. Analiza trendów odnosi się do badań i działań realizowanych na zróżnicowanych poziomach abstrakcji oraz ścisłości metodologicznej, w każdym jednak przypadku charakteryzuje się dążeniem do ujmowania i interpretowania zmian oraz określania ich znaczenia.

\section{Bibliografia}

Bernstein J., Transdisciplinarity: A Review of Its Origins, Development, and Current Issues, „Journal of Research Practice” 2015, Vol. 11, Issue 1, URL: http:// jrp.icaap.org/index.php/jrp/article/view/510/436, dostęp: 12.07.2019.

Brown T., Wyatt J., Design Thinking for Social Innovation, „Stanford Social Innovation Review", Winter 2010, URL: https://new-ideo-com.s3.amazonaws.com/ assets/files/pdfs/news/2010_SSIR_DesignThinking.pdf, dostęp: 8.10.2020.

Dawkins R., Samolubny gen, tłum. M. Skoneczny, Pruszyński i Spółka, Warszawa 2012.

Durst C., Durst M., Saffer M., Weak Signals, Hypes or Trends - Identify Innovation Opportunities and stay ahead of your Game, 2017, s. 5, doi: 10.13140/ RG.2.2.27409.02408. 
Fjord Trends 2019, URL: https://trends.fjordnet.com/Trends_2019_download. pdf, dostęp: 29.07.2019.

Future of an Ageing Population, Government Office for Science, OGL, London 2016, URL: https://www.ageing.ox.ac.uk/files/Future_of_Ageing_Report.pdf, dostęp: 11.07.2019.

Gadamer H.-G., Prawda i metoda. Zarys hermeneutyki filozoficznej. tłum. B. Baran, Wydawnictwo Naukowe PWN, Warszawa 2004.

Głosy w sprawie interdyscyplinarności. Socjologowie, filozofowie i inni o pojęciach, podejściach i swych doświadczeniach, red. J. Kurczewska, M. Lejzerowicz, Wydawnictwo IFiS PAN, Warszawa 2014.

Gordon T.J., Trend Impact Analysis, 1994, URL: http://www.foresight.pl/assets/ downloads/publications/Gordon1994-Trendimpact.pdf, dostęp: 22.02.2019.

Grondin J., Wprowadzenie do hermeneutyki filozoficznej, tłum. L. Łysień, Wydawnictwo WAM, Kraków 2007.

Halicka K., Prospektywna analiza technologii - metodologia i procedury badawcze, Oficyna Wydawnicza Politechniki Białostockiej, Białystok 2016.

Hines A., Bishop P., Thinking about the Future: Guidelines for Strategic Foresight, Hinesight, Houston 2015.

Hornowska E., Brzezińska A.I., Kaliszewska-Czeremska K., Appelt K., Rawecka J., Bujacz A., Paradoksalny efekt triangulacji?, „Edukacja” 2012, nr 4(120), s. $72-83$.

Horx M., 13-Future Trends. Zwei neue Trendbegriffe für 2018, URL: https://www. horx.com/future-trends/, dostęp: 11.02.2019.

Interdyscyplinarnie o interdyscyplinarności. Między idea a praktyką, red. A. Chmielewski, M. Dudzikowa, A. Grobler, Oficyna Wydawnicza „Impuls”, Kraków 2012.

Kahneman D., Pułapki myślenia. O myśleniu szybkim i wolnym, tłum. P. Szymczak, Wydawnictwo Media Rodzina, Poznań 2012.

Kita M., „Razem”: konsiliencja, interdyscyplinarność, transdyscyplinarność, w: Transdyscyplinarność badań nad komunikacja medialna, t. 1: Stan wiedzy $i$ postulaty badawcze, red. M. Kita, M. Ślawska, Wydawnictwo Uniwersytetu Śląskiego, Katowice 2012, URL: https://rebus.us.edu.pl/ bitstream/20.500.12128/2543/1/Kita_\%20Razem_konsiliencja_interdyscyplinarnosc_transdyscyplinarnosc.pdf, dostęp: 3.07.2019.

Kjaer A.L., The Trend Management Toolkit. A Practical Guide to the Future, Palgrave Macmillan, London 2014. 
Kucner A., Aksjologiczne i ontologiczne aspekty trendów, w: A. Kucner, G. Pacewicz, A. Rutkowska, R. Sierocki, J. Sobota, M. Sternicka-Kowalska, R. Szulc, M. Świgoń, P. Wasyluk, Trendy. Interpretacje i konfrontacje, Instytut Filozofii UWM w Olsztynie, Olsztyn 2018, URL: http://wmbc.olsztyn.pl/Content/5521/ Trendy_Interpretacje\%20i\%20konfrontacje-min.pdf, dostęp: 22.07.2019.

Kurczewska J., Wariacje na temat interdyscyplinarności, w: Oceny nauki, red. Sz. Biliński, Polska Akademia Umiejętności, Kraków 2014, s. 81, URL: http://pau. krakow.pl/Debaty_PAU/T_I/Debaty_PAU_I_dyskusja_Kurczewska.pdf, dostęp: 08.07.2019.

Mayer-Schönberg V., Cukier K., Big Data. Rewolucja, która zmieni nasze myślenie, prace i życie, tłum. M. Głatki, MT Biznes, Warszawa 2014.

Mikołajec J., Dwa typy dyfuzji innowacji i ich ontologiczne założenia, „Zeszyty Naukowe Politechniki Śląskiej” 2014, z. 72, s. 125-134.

Miles, M.B., Huberman A.M., Analiza danych jakościowych, tłum. S. Zabielski, Trans Humana Wydawnictwo Uniwersyteckie, Białystok 2000.

Pacewicz G., Konotacja i denotacja „trendu”, w: A. Kucner, G. Pacewicz, A. Rutkowska, R. Sierocki, J. Sobota, M. Sternicka-Kowalska, R. Szulc, M. Świgoń, P. Wasyluk, Trendy. Interpretacje i konforntacje, Instytut Filozofii UWM w Olsztynie, Olsztyn 2018, URL: http://wmbc.olsztyn.pl/Content/5521/Trendy_Interpretacje\%20i\%20konfrontacje-min.pdf, dostęp: 22.07.2019.

Pieriegud J., Wykorzystanie megatrendów do analizy przyszłościowego rozwoju sektorów gospodarki, w: Megatrendy i ich wplyw na rozwój sektorów infrastrukturalnych, red. J. Gajewski, W. Paprocki, J. Pieriegud, Instytut Badań nad Gospodarką Rynkową - Gdańska Akademia Bankowa, Gdańsk 2015.

Przyłębski A., Hermeneutyczny zwrot filozofii, Wydawnictwo Naukowe UAM, Poznań 2005.

Raymond M., The Trend Forecaster's Handbook, Laurence King Publishing, London 2010.

Rifkin J., Społeczeństwo zerowych kosztów krańcowych. Internet przedmiotów. Ekonomia współdzielenia. Zmierzch kapitalizmu, tłum. A.D. Kamińska, Wydawnictwo Studio EMKA, Warszawa 2016.

Rogers E., Diffusion of Innovations, The Free Press, New York, London 1983.

Rorty R., Intelektualista humanistyczny: jedenaście tez, w: tegoż, Filozofia a nadzieja na lepsze społeczeństwo, tłum. S. Tokariew, Wydawnictwo Naukowe Uniwersytetu Mikołaja Kopernika, Toruń 2013. 
Singh S., New Mega Trends: Implications for our Future Lives, Palgrave Macmillan, London 2012.

Skalska Z., New Normal. Trendbook 2019/2020, Nederlanse Interieur Instituut (NII), 2019.

Skalska Z., VUCA Times. Trend Book 2020/21, 360inspiration, Greenhat Innovation, 2020.

Smil V., Global Catastrophes and Trends. The Next 50 Years, The MIT Press, Cambridge, London 2012.

Stasik A., Narracje o przyszłości a projektowanie innowacji - perspektywa studiów nad nauka i technologia, „Stan Rzeczy” 2018, nr 1(14).

Tabaszewska J., „Wędrujące pojęcia”. Koncepcja Mieke Bal - przykład inter-czy transdyscyplinarności?, „Studia Europaea Gnesnensia” 2013, nr 8, s. 113-130, URL: http://bazhum.muzhp.pl/media//files/Studia_Europaea_Gnesnensia/Studia_Europaea_Gnesnensia-r2013-t8/Studia_Europaea_Gnesnensia-r2013-t8-s113-130/Studia_Europaea_Gnesnensia-r2013-t8-s113-130.pdf, dostęp: 12.07.2019.

Taleb N.N., Antykruchość. O rzeczach, którym służa wstrząsy, tłum. O. Siara, Kurhaus Publishing, Warszawa 2017.

Thaler R.H., Zachowania niepoprawne. Tworzenie ekonomii behawioralnej, thum. J. Konieczny, Wydawnictwo Media Rodzina, Poznań 2018.

The 2018 Ageing Report Underlying Assumptions \& Projection Methodologies, Publications Office of the European Union, Luxembourg 2017, URL: https:// ec.europa.eu/info/sites/info/files/economy-finance/ip065_en.pdf, dostęp: 11.07.2019.

Thinking about the Future. Guidelines Strategic Foresight, eds. A. Hines, P. Bishop, Social Technologies LLC, Houston 2015.

Trend and Future of Sustainable Development, eds. H. Lakkala, J. Vehmas, Finland Futures Research Centre, Helsinki 2011.

Voros J., A Generic Foresight Process Framework, „Foresight” 2005, Vol. 5, No. 3, s. 11, doi:10.1108/14636680310698379.

The VUCA-Report, The Strategic Agility Institute, 2016, URL: https://static1. squarespace.com/static/5579c941e4b00a23147233ce/t/56eff7f420c6474a7c d617ab/1458567164889/The_VUCA_Report_1.1_March_2016.pdf, dostęp: 22.02.2019. 
Wieczorek T., Triangulacja metod $w$ badaniach społecznych. „Zagadnienia Społeczne" 2014, nr 1(1), s. 15 i nn., URL: http://czasopismo.nwsp.pl/01\%20TWieczorek\%20Triangulacja\%20metod\%20w\%20badaniach_1(1)\%202014.pdf, dostęp: 5.08.2019.

World Population Ageing 2017 Highlights, United Nations, Department of Economic and Social Affairs, Population Division, 2017, URL: https://www. un.org/en/development/desa/population/publications/pdf/ageing/WPA2017_ Highlights.pdf, dostęp: 11.07.2019.

\section{Streszczenie}

Analiza trendów jest specyficznym podejściem badawczym, którego przedmiotem są obserwowalne zmiany, a orientację badań wyznacza przyszły, możliwy bieg zdarzeń i ich znaczenie. Analiza trendów łączy w sobie dwie perspektywy interpretacji zmian. Pierwszą - poznawczą, skoncentrowaną na analizie rzeczywistych danych, które służą rozumieniu procesów oraz są przesłanką do budowania scenariuszy przyszłości; drugą - aksjologiczną, służącą wartościowaniu procesów i szerzej rozumianemu sensemakingowi. Perspektywy te są komplementarne, a ich wynikiem jest krytyczne rozumienie zmian, a jednocześnie próba oceny ich znaczenia oraz wskazania możliwych następstw. Istotne staje się wtedy określenie ich wpływu na człowieka, kulturę czy środowisko w sposób, który przekracza ramy myślenia historycznego oraz wiedzy o wyłącznie obserwowalnych zjawiskach. Tak rozumiana analiza trendów łączy w sobie podejście inter- oraz transdyscyplinarne, jest hermeneutyką przyszłości i sposobem myślenia prospekcyjnego.

Słowa kluczowe: analiza trendów, hermeneutyka, myślenie prospekcyjne, analiza zmian, teoria rozumienia, interdyscyplinarność, transdyscyplinarność 


\section{Summary}

\section{Analysis of Trends in the Context of Hermeneutics and Prospective Thinking}

An analysis of trends is a specific research approach concentrated on noticeable changes. As an orientation of research, the analysis is determined by a future, possible course of events and their meaning. An analysis of trends combines two perspectives of interpretations of changes. The first perspective is cognitive, focused on an analysis of facts in order to use them in process understanding and used to create future scenarios. The other perspective is axiological, used in valuation of processes and for sensemaking. Both of these perspectives are complementary with a result in critical understanding of changes and, simultaneously, an attempt to evaluate their meaning and determine possible outcomes. Thus, their impact on human being, culture, and nature, regardless of historical patterns and empirical knowledge is the most important goal of research. An analysis of trends combines an inter- and transdisciplinary approach; it is a hermeneutics of the future and a way of prospective thinking.

Key words: analysis of trends, hermeneutics, prospective thinking, analysis of changes, theory of understanding, interdisciplinarity, transdisciplinarity 